\title{
PLANNING OF THE DIAGNOSTIC EXPERIMENT IN THE LOCALIZATION OF TROUBLESHOOTING FAILURES OF SINGLE-FREE SYSTEMS
}

\author{
S.A. Polozhaenko, L.L. Prokofieva
}

Odesa National Polytechnic University,

1, Shevchenko Ave., Odesa, 65044, Ukraine; e-mail: sanp@gmail.com, prokofieva1957@gmail.com

Formalized conditions for carrying out a diagnostic experiment associated with the identification of faulty fragments (subschemes) of inertial-free systems are obtained. The diagnostic experiment is reduced to computational procedures for localization of faulty subschemes, which are based on testing hypotheses that the characteristics of the allocated subschemes have changed. Hypotheses are formulated in such a way as to ensure the detection of parametric and structural faults. The first, for example, may include changing the resistance of the circuit, and the second - an open or short circuit. When the system is divided into subschemes, the latter are selected from the condition of their parametric identifiably, i.e. The situation when, based on the known parameters of the remaining subschemes, as well as the input and output signals in the whole system, it is possible to determine the parameters of the subscheme under consideration. Planning a diagnostic experiment is as follows. Assuming a linear relationship between the parameters of the allocated subscheme $S_{i}$ and the output signals of the system, a verification matrix $F$ is created in advance, which determines the interrelation of the indicated parameters and signals, considering the serviceability of the subscheme under consideration. In the event of a malfunction, the verification matrix $F$ changes, which allows to determine the nonconformity matrix $q$, on the basis of which analysis it is possible to obtain an estimate $\Delta \hat{\rho}_{i}$ of the parameters $\Delta \rho_{i}$ of the subscheme $S_{i}$ under consideration, as a result of which it is concluded that it is serviceable. Procedures for testing hypotheses on the health of the subschemes of the inertial-free system for cases of parametric and structural faults are of an identical nature. The principal difference between experiment planning and structural faults from planning for parametric faults is that for parametric faults the value $\Delta \rho_{i}$ does not depend on the input signals of the system, while for structural faults - the value $\Delta \rho_{i}$ depends on the input signals of the system, in an unknown way.

Keywords: diagnostics, diagnostic experiment, fault location, inertial-free systems, estimation of subschemes parameters

\section{Introduction}

To solve a wide range of problems in the study of systems (identification, control of operability, preventive maintenance), methods of the theory of experimental design are widely used, allowing, in the presence of measurement noise, to obtain estimates of the parameters of the system model that are best in some sense. It should also be taken into account that the features of the dynamic behavior of systems, for example, their lack of inertia, do not have a significant effect on the procedures for carrying out these experiments [1].

When diagnosing, even in the case of the most simple parametric faults in the subschemes, it is necessary first of all not to get the parameter estimates, but to establish the faulty subschemes. This formulation of the problem presupposes the need to ensure the best distinguish ability of the subschemes [2-4].

Objective of this article is formalization of the conditions for planning a diagnostic experiment in problems of determining the operability of inertial-free systems in the localization of parametric and structural faults in their subschemes. 


\section{Main part}

Suppose that in one of the subschemes only parametric faults are possible. In this case, the description of the faulty subscheme $S_{i}$ has the following form $Z_{i}=\varphi_{i}^{*}\left(V_{i}, \rho_{i}\right) ; i=\overline{1, N}$, where $Z_{i}$ - is the vector of the subschemes $S_{i}$ parameters, $\rho_{i}=\rho_{i}^{*}+\Delta \rho_{i} ; \rho_{i} \in D_{p}, D_{p}$ - the area of the values of the subscheme $S_{i}$ parameters, $\rho^{*}$ - the vector of the nominal values of the dimension $r_{i}$ parameters, $N$ - the number of subschemes to be checked.

A subscheme $S_{i}$ is parametrically identifiable if, with known parameters of the remaining subschemes, the input and output signals in the system as a whole can be determined by its subscheme $S_{i}$ parameters.

Consider the subscheme $S_{i}$ for which the relationship between the parameters and the output signals of the system is linear. In this case, the description of a system with a defective subscheme $S_{i}$ can be represented as follows:

$$
y=F^{*}(u)+\frac{\partial F^{*}(u)}{\partial \rho_{i}^{m}} \Delta \rho_{i}, i=\overline{1, N},
$$

where $y$ - the vector of the output signals of the system, $u$ - the vector of the input signals of the system, $F^{*}(u)$ - a verification matrix composed of the elements of the fault dictionary.

Denoting $\left\{\left[\partial F^{*}(u)\right] / \partial \rho_{i}^{\mathrm{T}}\right\}=q_{i}(u)$, we rewrite (1) in the form

$$
\Delta y=y-F^{*}(u)=q_{i}(u) \Delta \rho_{i}, i=\overline{1, N} .
$$

If there is such a value $u \in D_{u}$ as $\operatorname{rank} q_{i}(u)=r_{i}$, then from (2) we can obtain an estimate $\Delta \hat{\rho}_{i}$ of the parameters $\Delta \rho_{i}$. In this case, the identification task is solved with one set of input signals of the system. If the rank $q_{i}(u)<r_{i}$, then the task of identification can be solved only if on the diagnosed system it is possible to give sets of input signals $U^{\kappa}=\left(u^{1}, \ldots, u^{\kappa}\right)^{\mathrm{T}}$, in which $\operatorname{rank} Q_{i}\left(U^{\kappa}\right)=\operatorname{rank}\left[\begin{array}{l}q_{i}\left(u^{1}\right) \\ \vdots \\ q_{i}\left(u^{\kappa}\right)\end{array}\right]=r_{i}$.

Estimation of the parameters of the subsysteme $S_{i}$ is determined from equation

$$
\Delta Y\left(U^{\kappa}\right)=Q_{i}\left(U^{\kappa}\right) \Delta \rho_{i}, i=\overline{1, N}
$$

where $\Delta Y\left(U^{\kappa}\right)=\left[\Delta y\left(u^{1}\right), \ldots, \Delta y\left(u^{\kappa}\right)\right]^{\mathrm{T}}$.

The problem of diagnosing will be solved by testing hypotheses $H_{\rho_{i}}$. The hypothesis $H_{\rho_{i}}$, $i=\overline{1, N}$ is the assumption that the parameters of the subscheme $S_{i}$ have changed and the description of the system has the form (1).

The hypothesis $H_{\rho_{i}}$ is verified by testing the compatibility of equation (3), whose matrix $Q\left(U^{\kappa}\right)$ must be rectangular.

Subschemes $S_{i}, S_{j} ; i \neq j$ are not distinguishable under the hypothesis $H_{\rho_{i}}$, if for a given value $\Delta \rho_{j}$ there exists such a value $\Delta \rho_{i} \in D_{p}$ that

$$
q_{i}(u) \Delta \rho_{i}=q_{j}(u) \Delta \rho_{j}, u \in D_{u} .
$$


The criteria for the distinguish ability of the subschemes $S_{i}, S_{j}$ parameters are determined from the conditions under which equality (4) is not satisfied.

The parameters of the subschemes $S_{i}, S_{j}$ are distinguishable under the hypothesis $H_{\rho_{i}}$ if and only if there exists a value $U^{\kappa}$ such that

$$
\operatorname{rank}\left[Q_{i}\left(U^{\kappa}\right) \mid Q_{j}\left(U^{\kappa}\right)\right]=r_{i}+\operatorname{rank} Q_{j}\left(U^{\kappa}\right) .
$$

In this case, the subscheme $S_{j}$ parameters can be unidentifiable due to the fact that $\operatorname{rank} Q_{j}\left(U^{\kappa}\right)<r_{j}$.

Let us write down the necessary condition for the distinguish ability of the parameters of the subschemes $S_{i}, S_{j}$, under the hypothesis $H_{\rho_{\mathrm{i}}} \operatorname{rank}\left[Q_{i}\left(U^{\kappa}\right) \mid Q_{j, s}\left(U^{\kappa}\right)\right]=r_{i}+1 ; S=\overline{1, r_{j}}$, where $Q_{j, s}\left(U^{\kappa}\right)$ - is the $s$-th column of the matrix $Q_{j}$.

If only one parameter in the system is allowed to change, then condition (5) with respect to the distinguish ability of all the system parameters reduces to the existence of input signals of the system ensuring pair wise linear independence of the columns of the matrix $\left[Q_{1}\left(U^{\kappa}\right), \ldots, Q_{N}\left(U^{\kappa}\right)\right]$, where $N$ is the total number of parameters tested [5]. And linear independence of different columns can be achieved with different input signals of the system.

Planning a diagnostic experiment when estimating the subscheme parameters. Let the scalar output of $y$ be measured with an error. Assuming that only parametric faults can exist in the subscheme $S_{i}$ and the system model is linear in the parameters of the subsystems under test, the description of the faulty system is similar to (2) in the form $\Delta y+\xi=q_{i}(u) \Delta \rho_{i}$. Changing the values of the input signals of the system, we form, similarly to (3), a system of algebraic equations for obtaining estimates $\Delta \hat{\rho}_{i}$ of the parameters $\Delta \rho_{i}$ :

$$
\Delta \Lambda=Q_{i} \Delta \rho_{i},
$$

where $\Delta \Lambda=\left[\Delta y\left(u^{1}\right)+\xi^{1}, \ldots, \Delta y\left(u^{\kappa}\right)+\xi^{\kappa}\right]^{T}, Q_{i}=Q_{i}\left(U^{\kappa}\right)$.

Suppose that the measurement error values $\xi^{r}$ have a normal distribution with zero expectation $E\left[\xi^{r}\right]=0$ and the same variance $\sigma^{2}$, are not correlated with each other, and also with $q_{i}\left(u^{r}\right), \Delta \rho_{i}$. In this case, the quantities $\Delta y\left(u^{r}\right)+\xi^{r}, r=\overline{1, K}$ are independent, normally distributed, with mathematical expectation $\Delta y\left(u^{r}\right)$ and the same variance $\sigma^{2}$.

The assumptions made allow us to use the method of least squares to obtain an estimate $\Delta \hat{\rho}_{i}$ :

$$
\Delta \hat{\rho}_{i}=\left(Q_{i}^{\mathrm{T}} Q_{i}\right)^{-1} Q_{i}^{\mathrm{T}} \Delta \Lambda
$$

It is assumed that the matrix $Q_{i}^{\mathrm{T}} Q_{i}=F_{i}$, called the information matrix (the Fisher matrix), is no degenerate.

If the vector were measured without errors, then from (3) it would be possible to obtain exact (errors of computation are not considered) parameter values $\Delta \rho_{\mathrm{i}}=\left(Q_{i}^{\mathrm{T}} Q_{i}\right)^{-1} Q_{i}^{\mathrm{T}} \Delta Y$. The covariance matrix of estimates of the subscheme $S_{i}$ parameters is as follows: 


$$
\operatorname{cov}\left[\Delta \hat{\rho}_{i}\right]=E\left[\left(\Delta \hat{\rho}_{i}-\Delta \rho_{i}\right)\left(\Delta \hat{\rho}_{i}-\Delta \rho_{i}\right)^{\mathrm{T}}\right]=\sigma^{2} F_{i}
$$

Criteria for the optimal choice of input signals of the system are related to the form of the information matrix $F_{i}$ and are aimed at minimizing any of its characteristics, for example, the value of the determinant [6].

The foregoing experimental planning assumes that the faulty subscheme is known and it is only necessary to determine its parameters. If the faulty subscheme is unknown, then when evaluating the parameters of the scanned subscheme, it is necessary to ensure that the parameters of the subschema are discernible with the subscheme parameters, which can in fact be faulty.

Planning a diagnostic experiment for parametric faults. Consider the planning of an experiment aimed at ensuring the distinguish ability of the parameters of subsystems $S_{i}, S_{j}$, when estimating the parameters of the subsystem $S_{i}$.

We divide the diagnostic equation (6) into two parts:

$$
\begin{aligned}
& \Delta \Lambda_{\mathrm{a}}=Q_{i, \mathrm{a}} \Delta \rho_{i}, \\
& \Delta \Lambda_{\mathrm{b}}=Q_{i, \mathrm{~b}} \Delta \rho_{i} .
\end{aligned}
$$

The compatibility of equation (6) can be checked by checking the unbiasedness of the estimates $\Delta \hat{\rho}_{i}^{\mathrm{a}}, \Delta \hat{\rho}_{i}^{\mathrm{b}}$, the parameters $\Delta \rho_{i}$ obtained from equations (8) and (9), respectively. Analogously to (7) from (8) we obtain an estimate of the parameters

$$
\Delta \hat{\rho}_{i}^{\mathrm{a}}=\left(Q_{i, \mathrm{a}}^{\mathrm{T}} Q_{i, \mathrm{a}}\right)^{-1} Q_{i, \mathrm{a}}^{\mathrm{T}} \Delta \Lambda_{\mathrm{a}}=F_{i, \mathrm{a}} Q_{i, \mathrm{a}}^{\mathrm{T}} \Delta \Lambda_{\mathrm{a}}
$$

From (9) we obtain $\Delta \hat{\rho}_{i}^{\mathrm{b}}=F_{i, \mathrm{~b}} Q_{i, \mathrm{~b}}^{\mathrm{T}} \Delta \Lambda_{\mathrm{b}}$.

If the subscheme $S_{j}$ is faulty, the matrices $\Delta \Lambda_{\mathrm{a}}, \Delta \Lambda_{\mathrm{b}}$ are determined by expressions $\Delta \Lambda_{\mathrm{a}}=Q_{j, \mathrm{a}} \Delta \rho_{j}, \Delta \Lambda_{\mathrm{b}}=Q_{j, \mathrm{~b}} \Delta \rho_{j}$.

Because of measurement errors $\Delta \hat{\rho}_{i}^{\mathrm{a}}, \Delta \hat{\rho}_{i}^{\mathrm{b}}$, estimates are random quantities with some areas of distribution of their values.

Depending on which of the subscheme $\left(S_{i}\right.$ or $S_{j}$ ) is faulty, the mathematical expectation $E\left[\Delta \hat{\rho}_{i}^{\mathrm{a}}\right]$ and the covariance matrix $\operatorname{cov}\left[\Delta \hat{\rho}_{i}^{\mathrm{a}}\right]$ of the estimate $\Delta \hat{\rho}_{i}^{\mathrm{a}}$ obtained under the hypothesis $H$ are as follows:

$$
E\left[\Delta \hat{\rho}_{\mathrm{i}}^{\mathrm{a}}\right]= \begin{cases}F_{i, \mathrm{a}} Q_{j, \mathrm{a}}^{\mathrm{T}} \Delta \rho_{j}, & \text { at } j \neq i, \\ \Delta \rho_{i}, & \text { at } j=i,\end{cases}
$$

If any of the subschemes is faulty: $\operatorname{cov}\left[\Delta \hat{\rho}_{i}^{\mathrm{a}}=\sigma^{2} F_{i, \mathrm{a}}\right]=\sigma^{2} F_{i, \mathrm{a}}$. Similar expressions are also obtained for $E\left[\Delta \hat{\rho}_{i}^{\mathrm{b}}\right], \operatorname{cov}\left[\Delta \hat{\rho}_{i}^{\mathrm{b}}\right]$, by substituting in the expressions for $E\left[\Delta \hat{\rho}_{i}^{\mathrm{a}}\right], \operatorname{cov}\left[\Delta \hat{\rho}_{i}^{\mathrm{a}}\right]$, the index «a» by «b».

The bias in the estimate $\Delta \hat{\rho}_{i}$ is determined by the magnitude

$$
\rho_{i}=\Delta \hat{\rho}_{i}^{\mathrm{a}}-\Delta \hat{\rho}_{i}^{\mathrm{b}}
$$

The mathematical expectation and the covariance matrix of the vector $\rho_{i}$ are as follows: 


$$
\begin{aligned}
& E\left[\rho_{i}\right]= \begin{cases}m_{i, i}=\left(F_{i, \mathrm{a}} Q_{i, \mathrm{a}}^{\mathrm{T}} Q_{j, \mathrm{a}}-F_{i, \mathrm{~b}} Q_{i, \mathrm{~b}}^{\mathrm{T}} Q_{j, \mathrm{~b}}\right) \Delta \rho_{j}, & \text { at } j \neq i, \\
m_{i, j}=0, & \text { at } i=j,\end{cases} \\
& C_{i}=\operatorname{cov}\left[\rho_{\mathrm{i}}\right]=\sigma^{2}\left(F_{i, \mathrm{a}}+F_{i, \mathrm{~b}}\right) .
\end{aligned}
$$

As follows from (12), the covariance matrix of the vector $\rho_{\mathrm{i}}$ does not depend on which of the subschemes is faulty.

Let the system change only one parameter, i.e. $\Delta \rho_{i}-$ is a scalar. If the system of diagnostic equations (8), (9) consists of two scalar equations:

$$
\begin{aligned}
\Delta \Lambda_{i, \mathrm{a}} & =q_{i, \mathrm{a}} \Delta \rho_{i}, \\
\Delta \Lambda_{i, \mathrm{~b}} & =q_{i, \mathrm{~b}} \Delta \rho_{i},
\end{aligned}
$$

then

$$
\begin{gathered}
E\left[\rho_{i}\right]= \begin{cases}m_{i, i}=\left(\frac{q_{j, \mathrm{a}}}{q_{i, \mathrm{a}}}-\frac{q_{j, \mathrm{~b}}}{q_{i, \mathrm{~b}}}\right) \Delta \rho_{j}, & \text { at } j \neq i, \\
m_{i, j}=0, & \text { at } j=i,\end{cases} \\
\beta_{i}=D\left[\rho_{i}\right]=\delta^{2}\left(\frac{1}{q_{i, \mathrm{a}}^{2}}+\frac{1}{q_{i, \mathrm{~b}}^{2}}\right) .
\end{gathered}
$$

For this distinction of subschemes $S_{i}, S_{j}$, it is necessary that the distribution areas of the quantities $\rho_{i, i}\left(\rho_{i}\right.$ with a faulty subscheme $\left.S_{i}\right)$ and $\rho_{i, j}\left(\rho_{j}\right.$ with a faulty subscheme $\left.S_{j}\right)$ do not overlap.

As an example, Fig. 1 shows the distribution of two-dimensional quantities $\rho_{i, i}, \rho_{i, j}$. The situation shown in Fig. 1, a, is characterized with respect to the situation shown in Fig. 1, b, higher accuracy of parameter estimates $\Delta \hat{\rho}_{i}$, but lower distinguish ability of subschemes $S_{i}, S_{j}$.

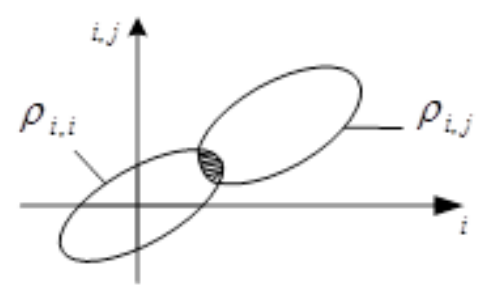

a

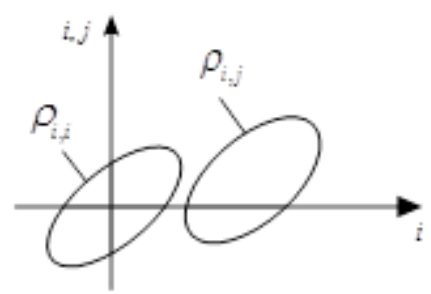

b

Fig. 1. Areas of distribution of two-dimensional quantities $\rho_{i, i}, \rho_{i, j}:$ a - situation with higher accuracy of parameter estimates $\Delta \hat{\rho}_{i} ; \mathrm{b}$ - situation with higher distinguish ability of subschemes $S_{i}$, $S_{j}$.

In the present paper, the problem of determining the optimal input signals of a system in the planning of a diagnostic experiment that ensure the distinguish ability of subschemes $S_{i}, S_{j}$ is considered as the problem of obtaining the maximum distance between the regions of distribution of the values of $\rho_{i, i}$ and $\rho_{i, j}$.

In the theory of pattern recognition, the distance of the Mahalanobis is widely used as a measure of the distance between sets [7]. Assume that the distribution of values $\rho_{i, i}, \rho_{i, j}$, obey the normal laws $N\left(m_{i, i}, C_{i}\right), N\left(m_{i, j}, C_{i}\right)$, where $m_{i, i}, m_{i, j}$ - are the vectors of mathematical expectation, $\mathbf{C}_{i}-$ is the covariance matrix of dimension. In this case, the 
generalized Mahalanobis distance between the regions of distribution $\rho_{i, i}$ and $\rho_{i, j}$ is determined by the expression

$$
I_{i, j}=M_{i, j}^{\mathrm{T}} C_{i}^{-1} M_{i, j}
$$

then $M_{i, j}=m_{i, i}-m_{i, j}$.

If the covariance matrix $C_{i}$ - is a single matrix, then $I_{i, j}$ it characterizes the quadratic distance between the mathematical expectations $\rho_{i, i}$ and $\rho_{i, j}$.

For one-dimensional normally distributed sets of values $\rho_{i, i}$ and $\rho_{i, j}$, expression (13) takes the form

$$
I_{i, j}=\frac{\left(m_{i, i}-m_{i, j}\right)^{2}}{\beta_{i}} .
$$

Since according to (11) $m_{i, i}=0$, then (13), (14) can be written accordingly:

$$
\begin{gathered}
I_{i, j}=m_{i, j} C_{i}^{-1} m_{i, j}, \\
I_{i, j}=\frac{m_{i, j}^{2}}{\beta_{i}} .
\end{gathered}
$$

For calculations using formulas (15), (16), it is necessary to know the value $m_{i, j}$, which, according to (12), depends on the unknown value $\Delta \rho_{j}$.

If $\Delta \rho_{j}-$ is a scalar, i.e. only one parameter in the system is allowed to change, the maximum value $I_{i, j}$ obtained for an arbitrary value $\Delta \rho_{j} \neq 0$ of for $u=u^{0}$ is the maximum (but different in magnitude) for any value $\Delta \rho_{j}$. It follows from this that the optimal input signals $u^{0}$, at which the best distinguish ability of the subschemes $S_{i}, S_{j}$ is achieved, can be determined before the diagnostic experiment at an arbitrary value $\Delta \rho_{j}$ by maximizing the value $I_{i, j}$.

If $\Delta \rho_{j}-$ is a vector, then it is impossible to obtain optimal values $u^{0}$ beforehand before the diagnostic experiment, delivering a maximum $I_{i, j}$ for any values $\Delta \rho_{j}$. This is due to the fact that the value $m_{i, j}$ depends on the combination of the values of the components of the vector $\Delta \rho_{j}$. In this case, the choice of input signals aimed at ensuring the distinguish ability of subschemes $S_{i}, S_{j}$ can be carried out during the diagnostic experiment. Consider one of the variants of the experiment, consisting of two stages.

At the first stage, the estimates of the parameters of all subsystems are determined successively $\Delta \hat{\rho}_{1}, \ldots, \Delta \hat{\rho}_{N}$. The input signals of the system at this stage are selected from the conditions of optimal experiment planning for identifying the parameters of the corresponding subsystem. Among the estimates obtained $\Delta \hat{\rho}_{1}, \ldots, \Delta \hat{\rho}_{N}$, only one corresponds to the true values of the parameters of the faulty subsystem.

At the second stage, the optimal input signals of the system are determined, allowing selection of the obtained estimates $\Delta \hat{\rho}_{1}, \ldots, \Delta \hat{\rho}_{N}$ under the appropriate hypothesis. In this case, the criterion of optimality under the hypothesis $H_{\rho_{\mathrm{i}}}$ is the maximum of the quantity 
calculated by formula (13). In calculations according to formula (11), an estimate from $\Delta \hat{\rho}_{1}, \ldots, \Delta \hat{\rho}_{N}$ the set corresponding to the subsystem is used, with respect to which the distinguishable subscheme $S_{i}$ is distinguishable.

Use to test the hypothesis $H_{\rho_{i}}$ of the magnitude of the bias of the estimate $\Delta \hat{\rho}_{i}$, determined by the expression (10), is possible only if for matrices $Q_{i, \mathrm{a}}, Q_{i, \mathrm{~b}}$, there are minors of rank $r_{i}$. If for one of the matrices, for example $Q_{i, \mathrm{~b}}$, the matrix does not have a minor of rank $r_{i}$, then the reliability of the estimate $\Delta \hat{\rho}_{i}^{\mathrm{a}}$ can be checked by the criterion of the forecast of the output signal of the system.

In this case, an estimate $\Delta \hat{\rho}_{i}=F_{i, \mathrm{a}} Q_{i, \mathrm{a}}^{\mathrm{T}} \Delta \Lambda_{\mathrm{a}}$ is determined from (7), and then, according to (10), the quantity $\Delta \hat{\Lambda}_{\mathrm{b}}=Q_{i, \mathrm{~b}} \Delta \hat{\rho}_{\mathrm{i}}$. Error forecast

$$
\mu_{i}=\Delta \Lambda_{\mathrm{b}}-\Delta \hat{\Lambda}_{\mathrm{b}}
$$

is an indicator of the correctness of the hypothesis $H_{\rho_{i}}$. If $\mu_{i}<\boldsymbol{\varepsilon}_{i}$ that hypothesis $H_{\rho_{i}}$ is accepted, otherwise - it is rejected $\left(\boldsymbol{\varepsilon}_{i}-\right.$ an acceptable value $\left.\mu_{i}\right)$.

The value $\mu_{i}$ depends on which subsystem is actually faulty. If we consider subschemes $S_{i}, S_{j}$, then the mathematical expectation and variance of the quantities $\mu_{i}$ are determined by the expressions

$$
\begin{gathered}
E\left[\mu_{i}\right]= \begin{cases}\mu_{i, j}=Q_{i, \mathrm{~b}} F_{i, \mathrm{a}} Q_{i, \mathrm{a}}^{\mathrm{T}} \Delta \rho_{j}, & \text { at } j \neq i, \\
\mu_{i, j}=0, & \text { at } j=i,\end{cases} \\
\operatorname{cov}\left[\mu_{i}\right]=\sigma^{2}\left(1+Q_{i, \mathrm{~b}}^{\mathrm{T}} F_{i, \mathrm{a}} Q_{i, \mathrm{~b}}\right),
\end{gathered}
$$

where 1 - is the unit diagonal matrix.

The criterion of optimality of input signals for a hypothesis $H_{\rho_{i}}$ oriented to the determination of a defective subschemes $S_{i}, S_{j}$ in a pair can be the maximum of (15), where $m_{i, j}$ it should be put equal $\mu_{i, j}$, and $C_{i}=\operatorname{cov}\left[\mu_{i}\right]$. Otherwise, for the criterion based on the expression (18), the reasoning given for the criterion based on the expression (10) can be repeated.

Planning a diagnostic experiment for structural faults. Let us consider subsystems with independent observation. When testing the hypothesis $H_{i}: \Delta y=L_{i}(u) \Delta Z_{i}, i=\overline{1, N}$ (where $L_{i}$ - is the class of operators that specifies a class of faults in the subscheme $S_{i}$ [1]), the compatibility of equations of the form is verified:

$$
\begin{aligned}
& \Delta Y_{\mathrm{a}}+\xi_{\mathrm{a}}=L_{i, \mathrm{a}} \Delta Z_{i}, \\
& \Delta Y_{\mathrm{b}}+\xi_{\mathrm{b}}=L_{i, \mathrm{~b}} \Delta Z_{i} .
\end{aligned}
$$

In this case $\Delta Y_{\mathrm{a}}, \Delta Y_{\mathrm{b}}$, as well $\xi_{a}, \xi_{\mathrm{b}}$, are vectors whose dimensions are equal to or greater than the dimension of the vector $\Delta Z_{\mathrm{i}}$. 
Let the decision on the reliability of the hypothesis $H_{i}$ be made by the criterion of unbiasedness of the estimate $\Delta \hat{Z}_{i}$. Offsetting of the estimate $\Delta \hat{Z}_{i}$ is similar to (10) determined by the quantity

$$
\tau_{\mathrm{i}}=\Delta \hat{Z}_{i}^{\mathrm{a}}-\Delta \hat{Z}_{i}^{\mathrm{b}}
$$

If the matrix $L_{i, \mathrm{a}}$ is rectangular and the method of least squares is used to obtain the estimate $\Delta \hat{Z}_{i}^{\mathrm{a}}$ of the vector $\Delta Z_{i}$ from equation (20), then

$$
E\left[\Delta \hat{Z}_{\mathrm{i}}^{\mathrm{a}}\right]= \begin{cases}\theta_{i, \mathrm{a}} L_{i, \mathrm{a}}^{\mathrm{T}} L_{j, \mathrm{a}} \Delta Z_{j}, & \text { at } j \neq i, \\ \Delta Z_{\mathrm{i}}, & \text { at } j=i,\end{cases}
$$

where $\theta_{i, \mathrm{a}}=\left(L_{i, \mathrm{a}}^{\mathrm{T}} L_{i, \mathrm{a}}\right)^{-1}$.

The estimate $\Delta \hat{Z}_{i}^{\mathrm{b}}$ of the vector $\Delta \mathrm{Z}_{i}^{\mathrm{b}}$ from equation (21) is determined in a similar way.

The value $\tau_{i}$ determined by the hypothesis $H_{i}$ depends on which subscheme is actually faulty. Consider the case where only one of the subschemes $S_{i}, S_{j}$. can be faulty. Analogously to (11), (12) we obtain

$$
\begin{gathered}
E\left[\tau_{i}\right]= \begin{cases}\tau_{i, j}=\left(\theta_{i, \mathrm{a}} L_{i, \mathrm{a}}^{\mathrm{T}} L_{j, \mathrm{a}}-\theta_{i, \mathrm{~b}} L_{i, \mathrm{~b}}^{\mathrm{T}} L_{j, \mathrm{~b}}\right) \Delta Z_{j}, & \text { at } j \neq i, \\
\tau_{i, i}=0, & \text { at } j=i,\end{cases} \\
\operatorname{cov}[\tau]=\sigma^{2}\left(\theta_{i, \mathrm{a}}+\theta_{i, \mathrm{~b}}\right) .
\end{gathered}
$$

For the case when $\Delta \mathrm{Z}_{i}, \Delta \mathrm{Z}_{j}-$ are scalar quantities, that is, subschemes $S_{i}, S_{j}$, have one output, we get

$$
\begin{gathered}
E\left[\tau_{i}\right]= \begin{cases}\tau_{i, j}=\left(\frac{L_{j, \mathrm{a}}}{L_{i, \mathrm{a}}}-\frac{L_{j, \mathrm{~b}}}{L_{i, \mathrm{~b}}}\right) \Delta Z_{j}, & \text { at } j \neq i, \\
\tau_{i, i}=0, & \text { at } j=i,\end{cases} \\
D\left[\tau_{i}\right]=\sigma^{2}\left(\frac{1}{L_{i, \mathrm{a}}^{2}}+\frac{1}{L_{i, \mathrm{~b}}^{2}}\right) .
\end{gathered}
$$

The principal difference between experiment planning and structural faults from planning for parametric faults $\Delta \rho_{i}$ is that for parametric faults the value does not depend on the input signals of the system, while for structural faults the value $\Delta \rho_{i}$ depends on the input signals of the system, in an unknown way.

Let the observability matrices $L_{i, \mathrm{a}}, L_{i, \delta}, L_{j, \mathrm{a}}, L_{j, \delta}$ - be constants and $\Delta \mathrm{Z}_{j}$ - be a scalar quantity. In this case, when organizing a diagnostic experiment, two stages can be distinguished.

The first stage of the connection with the formation of observability matrices before the diagnostic experiment by means of an appropriate selection of control points. The choice of control points is carried out from the condition of maximum value (21), where $m_{i, j}$ it is replaced by $\tau_{i, j}$, and $C_{i}$ by $\operatorname{cov}\left[\tau_{i}\right]$. Since the maximum value $I_{i, j}$ obtained for the corresponding set of control points for arbitrary values $\Delta \mathrm{Z}_{j} \neq 0$ remains the maximum (but 
different in magnitude) for any values $\Delta \mathrm{Z}_{j}$, the choice of control points can be carried out at arbitrary values $\Delta \mathrm{Z}_{j} \neq 0$.

The second stage is realized during the diagnostic experiment. Since the observability matrices are constant in this case, no increase in noise occurs when the input signals of the system change, which follows from (24). With a faulty subscheme $S_{j}$, we have $\Delta y_{\mathrm{a}}=L_{j, \mathrm{a}} \Delta Z_{j}, \Delta y_{\mathrm{b}}=L_{j, \mathrm{~b}} \Delta Z_{j}$. In this case, the quantity $\tau_{i, j}$ in expression (23) corresponds to the quantity $\tau_{i, j}^{*}=\theta_{i, \mathrm{a}} L_{i, \mathrm{a}}^{\mathrm{T}} \Delta y_{\mathrm{a}}-\theta_{i, \mathrm{~b}} L_{i, \mathrm{~b}}^{\mathrm{T}} \Delta y_{\mathrm{b}}$.

The input signals of the system that ensure the best distinguish ability of the subschemes $S_{i}, S_{j}$ under the hypothesis $H_{i}$ are chosen in the second stage from the condition of the maximum of the quantity (21), where $m_{i, j}$ it is replaced by $\tau_{i, j}^{*}$, and $C_{i}-$ by $\operatorname{cov}\left[\tau_{i}\right]$.

When choosing control points, a table of coverings is usually constructed, the columns of which correspond to pairs of subsystems whose distinguishability is estimated, and the rows to checkpoints. At the intersection of a row and a column, there is one if some pair of subsystems are distinguishable by the introduction of the corresponding control point. The minimum set of control points corresponds to the minimum coverage of the table. There can be several minimal coverages, the choice of which is not formalized.

In some cases, for example, as described in this section, instead of one in the table of coverings, one can record the corresponding value of the Mahalanobis distance and from the minimal coverages choose a cover that provides a maximum, in some sense, distinguish ability of the subsystems. The criterion for choosing such a minimum coverage can be, in particular, the maximum value of the sum of all elements of the minimal coverage table.

If there is a limit on the number of channels of signal transmission from control points to the diagnostic system, the diagnostic system can be equipped with a diagnostic surveillance system. The diagnostic monitoring system is an adder whose inputs are connected to control points, and the output is to a communication channel. The weighting factors of the adder are chosen from the conditions for maximum discrimination of the subsystems on the basis of the Mahalanobis distance analysis for given ones.

\section{Conclusion}

For cases of parametric and structural faults obtained evaluation to test hypotheses about the distinctiveness of faulty subschemes in freewheeling systems. These estimates allow to identify faulty subscheme and plan their computational experiments based on the analysis of localization parameters subschemes diagnosable system to the test exposure. In this case, hypotheses are formulated from the assumption that the parameters of the diagnosed subscheme have changed. The localization of faulty system subschemes during the diagnostic experiment is carried out from the assumption of the distinguish ability of the subschemes, i.e. the partitioning of the system into subschemes must be carried out in such a way that the regions of distribution of the parameters of the subschemes do not intersect.

\section{References}

1. Верлань, А. Ф. Локализация неисправных фрагментов при диагностировании безынерционных систем / А. Ф. Верлань, С. А. Положаенко // Електротехнічні та комп'ютерні системи: Теорія і практика. Спеціальний випуск. Астропрінт. - 2017. - С. 439- 445.

2. Верлань, А. А. Декомпозиционный метод локализации неисправных электронных подсхем / А. А. Верлань, С. А. Положаенко, И. Х. Осман // Электромашиностроение и 
электрооборудование. - 2007. - Вып. 69. - С. 72-76.

3. Верлань, А. А. Формализация представления последовательности тестовых гипотез при диагностировании электронных схем / А. А. Верлань, Ю. Стертен, С. А. Положаенко // Информатика и математические методі в моделировании. - 2016. - Vol. 6, № 4. - P. 315321.

4. Положаенко, С. А. Локализация неисправных электронных подсхем методом обучающих и проверочных характеристик / С. А. Положаенко, А. А. Верлань, И. Х. Осман // Математичне та комп'ютерне моделювання. Серія: Технічні науки: зб. наук. пр. - Кам'янецьПодільський: Кам’янець-Подільськ. нац. ун-т, 2008. - Вип. 1. - С. 140-144.

5. Кулик, А. С. Диагностируемость линейных непрерывных систем / А. С. Кулик // Автоматика и телемеханика. — 1987. — № 6. - С. 148-155.

6. Круг, Г. К. Планирование эксперимента в задачах идентификации и экстраполяции / Г. К Круг, Ю. А. Сосулин, В. А. Фатуев. - М.: Наука, 1997. — 208 с.

7. Ту, Дж. Принципы распознавания образов / Дж. Ту, Р. Гансалес. - М.: Мир, 1978. - 411 с.

\title{
ПЛАНУВАННЯ ДІАГНОСТИЧНОГО ЕКСПЕРИМЕНТУ ПРИ ЛОКАЛІЗАЦІЇ НЕСПРАВНОСТЕЙ ПІДСХЕМ БЕЗІНЕРЦЙНИХ СИСТЕМ
}

\author{
С.А. Положаєнко, Л.Л. Прокофьєва
}

Одеський національний політехнічний університет,

просп. Шевченка, 1, Одеса, 65044, Україна; e-mail: sanp277@gmail.com, prokofieva1957@gmail.com

Отримано формалізовані умови проведення діагностичного експерименту. пов'язаного з виявленням несправних фрагментів (підсхем) безінерційних систем. Діагностичний експеримент зведено при цьому до обчислювальних процедур локалізації несправних підсхем, в основу яких (процедур) покладено перевірку гіпотез про те, що змінилися характеристики виділених підсхем. Гіпотези формулюються таким чином, щоб забезпечити виявлення параметричних та структурних несправностей. До перших, наприклад, можуть відноситися зміни опору ділянки ланцюга, а до других - обрив або коротке замикання. При розбитті системи на підсхеми, останні обираються за умови можливості їх параметричної ідентифікації. Тобто ситуації, коли по відомих параметрах інших підсхем, а також вхідних та вихідних сигналах системи в цілому, можна визначити параметри підсхеми, яка розглядається. Планування діагностичного експерименту полягає у наступному. Передбачаючи лінійну залежність між параметрами виділеної підсхеми $S_{i}$ та вихідними сигналами системи, завчасно складається перевірочна матриця $F$, яка визначає взаємозв'язок вказаних параметрів та сигналів, враховуючи справність підсхеми, що розглядається. При виникненні несправностей перевірочна матриця $F$ змінюється, що дозволяє визначити матрицю невідповідності $q$, на підставі аналізу якої можна отримати оцінку $\Delta \hat{\rho}_{i}$ параметрів $\Delta \rho_{i}$ підсхеми $S_{i}$, яка розглядається. В результаті даного аналізу робиться висновок щодо працездатності підсхеми $S_{i}$. Процедури перевірки гіпотез щодо справності підсхем без інерційної системи для випадків параметричних та структурних несправностей мають ідентичний характер. Принципова відмінність планування експериментів при структурних несправностях від планування при параметричних несправностях полягає у тому, що при параметричних несправностях величина $\Delta \rho_{i}$ не залежить від вхідних сигналів системи, а при структурних - величина $\Delta \rho_{i}$ залежить від вхідних сигналів системи, причому невідомим чином.

Ключові слова: діагностика, діагностичний експеримент, локалізація несправностей, безінерційні системи, оцінювання параметрів підсхем 


\title{
ПЛАНИРОВАНИЕ ДИАГНОСТИЧЕСКОГО ЭКСПЕРИМЕНТА ПРИ ЛОКАЛИЗАЦИИ НЕИСПРАВНОСТЕЙ ПОДСХЕМ БЕЗЫНЕРЦИОННЫХ СИСТЕМ
}

\author{
С.А. Положаенко, Л.Л. Прокофьєва
}

Одесский национальний политехнический университет, просп. Шевченко, 1, Одесса, 65044, Украина; е-mail: sanp277@ gmail.com, prokofieva1957@ gmail.com

Получены формализованные условия проведения диагностического эксперимента, связанного с выявлением неисправных фрагментов (подсхем) безынерционных систем. Диагностический эксперимент сводится при этом к вычислительным процедурам локализации неисправных подсхем, в основу которых (процедур) положена проверка гипотез о том, что изменились характеристики выделенных подсхем. Гипотезы формулируются таким образом, чтобы обеспечить выявление параметрических и структурных неисправностей. К первым, например, могут относиться изменение сопротивления участка цепи, а ко вторым - обрыв или короткое замыкание. При разбиении системы на подсхемы, последние выбираются из условия их параметрической идентифицируемости, т.е. ситуации, когда по известным параметрам остальных подсхем, а также входным и выходным сигналам в целом системы, можно определить параметры рассматриваемой подсхемы. Планирование диагностического эксперимента состоит в следующем. Предполагая линейную зависимость между параметрами выделенной подсхемы $S_{i}$ и выходными сигналами системы, заранее составляется проверочная матрица $F$, определяющая взаимосвязь указанных параметров и сигналов, учитывая исправность рассматриваемой подсхемы. При возникновении неисправности проверочная матрица $F$ изменяется, что позволяет определить матрицу несоответствия $q$, на основании анализа которой можно получить оценку $\Delta \hat{\rho}_{i}$ параметров $\Delta \rho_{i}$ рассматриваемой подсхемы $S_{i}$, в результате чего сделать заключение об ее исправности. Процедуры проверки гипотез об исправности подсхем безынерционной системы для случаев параметрических и структурных неисправностях имеют идентичный характер. Принципиальное отличие планирования эксперимента при структурных неисправностях от планирования при параметрических неисправностях состоит в том, что при параметрических неисправностях величина $\Delta \rho_{i}$ не зависит от входных сигналов системы, а при структурных - величина $\Delta \rho_{i}$ зависит от входных сигналов системы, причем неизвестным образом.

Ключевые слова: диагностика, диагностический эксперимент, локализация неисправностей, безынерционные системы, оценивание параметров подсхем 